\title{
PENGARUH KEMUDAHAN PENGGUNAAN, NILAI TIDAK TERGANTIKAN, KUALITAS SISTEM, KESADARAN TEKNOLOGI DAN DESAIN VISUAL TERHADAP POSITIF WORD OF MOUTH DAN NIAT PEMBELIAN ULANG DENGAN MEDIASI LOYALITAS MEREK
}

\author{
Ali Wardhana*1 \\ Yulia $^{2}$ \\ Manajemen, Fakultas IImu Sosial dan Humaniora, Universitas Bunda Mulia, Indonesia
}

\begin{abstract}
Abstrak
Dewasa ini smartphone sudah menjadi kebutuhan, sehingga para pemangku perlu mengetahui dampak kemudahan penggunaan, nilai yang tidak tergantikan, kualitas sistem, kesadaran teknologi dan desain visual terhadap niat pembelian ulang dan positif word of mouth dengan mediasi loyalitas merek. Dengan mengetahui dampak tersebut maka perusahaan, terkhususnya yang sedang mengalami perlambatan pertumbuhan dapat menggunakan nya utnuk mengakuisisi konsumen baru maupun meningkatkan pembelian ulang. Hasil penelitian menunjukan bahwa hanya 2 variabel yang dapat digunakan untuk meningkatkan positif word of mouth dan niat pembelian ulang dengan dimediasi oleh loyalitas merek, yaitu kualitas sistem dan kesadaran teknologi. Penelitian ini juga menunjukan bahwa kemudahan penggunaan dan nilai yang tidak tergantikan dirasa sudah tidak relevan dalam meningkatkan loyalitas merek mengingat smartphone sudah menjadi produk yang banyak digunakan sehari hari dengan beragamnya produk serupa dipasar.
\end{abstract}

Kata Kunci: Kualitas sistem ; Kesadaran teknologi ; kesetiaan merek ; niat pembelian ulang ; positif WOM

\begin{abstract}
Nowadays smartphones have become a necessity, so policy makers need to understand usage, irreplaceable value, system quality, technological awareness and visual design of repurchase commitments and positive word of mouth with mediating brand loyalty. By knowing the impact, companies, especially those who are increasing growth slowdown can use it to acquire new consumers and also increase repurchases. The results showed that only 2 variables could be used to increase positive word of mouth and repurchase goals mediated by brand loyalty, namely system quality and technological awareness. This study also shows that the use and value that is irreplaceable is considered irrelevant in increasing brand loyalty considering that smartphones have become a widely used product every day with a variety of products that are marketed.
\end{abstract}

Keyword: System Quality ; technology consciousness; brand loyalty ; repurchase intention ; positive WOM

Article History: Received: (16-01-2020); Revised: (22-02-2020); and Published: (30-04-2020) Copyright (c) 2020 Ali Wardhana, Yulia

How to cite this article: Wardhana, A., dan Yulia. (2020). Pengaruh kemudahan penggunaan, nilai tidak tergantikan, kualitas sistem, kesadaran teknologi, dan desain visual terhadap positif word of mouth dan niat pembelian ulang dengan mediasi loyalitas merek. Managament Insight: Jurnal IImiah Manajemen. 15(1), 65-77 


\section{PENDAHULUAN}

Dewasa ini Indonesia sudah menjadi pasar utama produsen smartphone dari berbagai negara di dunia dimana pada kuartal ke 3 tahun 2018 pasar Indonesia di kuasai oleh 3 vendor asal tiongkok, yaitu Vivo, Oppo dan Xiaomi dimana ketiga merk tersebut menguasai lebih dari separuh pangsa pasar di Indonesia atau sebesar $56 \%$ (Pertiwi, 2018). Senada dengan hal tersebut, riset oleh Canalys menunjukan bahwa sampai dengan kuartal ke 42018 merek samsung masih menduduki posisi puncak dengan dengan pangsa pasar yang mencapai $25,4 \%$ (Alto, 2019). Namun jika melihat lebih lanjut posisi lima besar nampak bahwa terdapat tiga pemain asal tiongkok yaitu, xiaomi, vivo dan oppo dimana terdapat 2 merek yang tumbuh secara luar biasa, yaitu merek xiaomi yang bertumbuh sebesar $139,4 \%$ dan merek vivo yang bertumbuh dalam 132\% (Alto, 2019). Berkebalikan dengan kedua merek senegaranya, merek oppo bertumbuh hanya $0,8 \%$ walaupun demikian merek oppo masih menduduki peringkat ketiga di Indonesia. Perlambatan pertumbuhan tersebut tentu saja harus menjadi perhatian bagi pemegang merek Oppo untuk mencari cara menaikan penjualan. Salah satu cara yang dapat digunakan oleh perusahaan adalah dengan menggunakan loyalitas merk (brand loyalty). Konsep loyalitas merek merupakan konsep yang banyak digunakan dalam pemasaran dan dapat memberikan dampak baik pada niat pembelian ulang (repurchase intention) (Can dan Erdil, 2018) maupun terhadap positif word of mouth (liao et al,2010). Dengan kata lain bila semakin tinggi setia konsumen terhadap sebuah merek, maka semakin tinggi pula konsumen tersebut untuk membeli ulang sebuah merek pada masa yang akan datang dan juga akan menjadi word of mouth yang dapat menarik konsumen baru

Pada niat pembelian ulang (repurchase intention), loyalitas merk (brand loyalty) yang merupakan sikap positif terhadap merek akan terus membeli secara teratur dalam jangka panjang (Can dan Erdil, 2018). Loyalitas merek sendiri sudah lama digunakan agar penjualan dapat terus dijaga dengan biaya yang lebih murah dibanding memperoleh konsumen baru. Pada sisi konsumen baru, word of mouth memberikan dampak positif bagi niat beli konsumen (Khan et al, 2015) bahkan positif word of mouth dapat digunakan untuk mengakuisisi konsumen baru (East et al, 2017). Dengan demikian konsep loyalitas merek (brand loyalty) dapat diyakini dapat digunakan untuk mempertahankan pangsa pasar oppo di Indonesia dan mendapatkan konsumen baru. Lantas variabel apa yang dapat digunakan untuk membangun loyalitas merek tersebut? Penelitian terdahulu Can dan Erdil (2018) mengungkapkan jika terkait smartphone maka terdapat lima variabel yang berpengaruh pada niat pembelian ulang melalui loyalitas merek, yaitu kemudahan penggunaan (perceived ease of use), nilai yang tidak tergantikan (perceived irreplaceability), kualitas sistem, kesadaran teknologi (technology consciousness) dan desain visual. Lebih lanjut hasil penelitian tersebut mengungkapkan bahwa hanya nilai yang tidak tergantikan (perceived irreplaceability), 
kualitas sistem, dan desain visual yang memberi pengaruh terhadap niat pembelian ulang, sedangkan pada kedua variabel lain tidak memberikan dukungan.

Dalam rangka mempertahankan pangsa pasar dapat juga menggunakan positif word of mouth, dikatakan bahwa orang akan berespon lebih terhadap positif word of mouth dan lebih terbuka untuk dipengaruhi oleh positif word of mouth (East et al, 2017) dimana positif word of mouth sendiri memiliki korelasi positif dengan kesetiaan merek (Wong et al,2015). Dengan demikian kesetiaan merek pada penelitian ini digunakan untuk melihat pengaruhnya terhadap niat pembelian ulang dan positif WOM. Pada penelitian ini kembali menggunakan kelima variabel, yang diyakini akan memberikan hasil yang berbeda sehingga mampu memperkuat maupun melengkapi dengan penelitian terdahulu khususnya pada merek yang sedang mengalami perlambatan pertumbuhan pada produk berteknologi tinggi seperti smartphone. Penelitian ini juga memiliki tujuan untuk mengetahui variabel yang memberi dampak terhadap terhadap niat pembelian ulang dan positif word of mouth melalui loyalitas merek. Merujuk pada penelitian terdahulu dan fenomena yang terjadi pada produk smartphone dengan merek Oppo maka penelitian ini bertujuan untuk mengetahui dampak kemudahan penggunaan (perceived ease of use), nilai yang tidak tergantikan (perceived irreplaceability), kualitas sistem, kesadaran teknologi (technology consciousness) dan desain visual terhadap niat pembelian ulang dan positif word of mouth dengan mediasi loyalitas merek.

\section{TINJAUAN PUSTAKA}

\section{Kemudahan Penggunaan (Perceived Ease of Use)}

Kemudahan penggunaan (Perceived ease of use) didefinisikan sebagai persepsi keseluruhan pengguna yang berkaitan dengan kenyamanan membeli sistem seluler melalui ponsel mereka sehingga konsep ini menjadi konstruksi utama untuk menguji dan menilai penerimaan pengguna terhadap teknologi tertentu. (Amin dan Abolghasemi, 2014). Bagi smartphone kemudahan penggunaan dapat digambarkan sebagai masalah navigasi kemudahan pada perangkat dan ketersediaan elemen yang dipersonalisasi (Park dan Chen, 2007). Lebih lanjut kemudahaan penggunaan ini akan berdampak positif pada sikap terhadap smartphone dan ketika pengguna smartphone memiliki persepsi negatif tentang kemudahan, sulit bagi mereka untuk mengidentifikasi nilai kegunaan smartphone.

H1 = Perceived ease of use (nilai kemudahaan penggunaan) memberi dampak terhadap brand loyalty (loyalitas merek) 


\section{Nilai yang Tidak Tergantikan (Perceived Irreplaceability)}

Nilai yang tidak tergantikan merupakan nilai didasarkan pada persepsi tentang kegunaan unik (Pedeliento dan Bergamaschi, 2016) dan ketika suatu produk dinilai tidak tergantikan, ia memiliki simbol (Schifferstein dan Pelgrim, 2008). Dengan kata lain nilai yang tidak tergantikan (Perceived irreplaceability) merujuk pada persepsi pengguna smartphone dimana smartphone memiliki keunikan yang tidak tergantikan dengan smartphone sejenis.

Nilai yang tidak tergantikan (perceived irreplaceability) diyakini memiliki dampak positif terhadap smartphone (pedeliento dan Bergamaschi, 2016) sehingga tidak mengherankan jika setiap pabrikan smartphone berlomba lomba menciptakan keunikan seperti oppo vooc flash charging yang kemudian diikuti oleh competitor yang lain

H2 = Perceived irreplaceability (nilai yang tidak tergantikan) memberi dampak terhadap brand loyalty (loyalitas merek)

\section{Kualitas Sistem (System Quality)}

Kualitas sistem dapat didefinisikan sebagai fisik ponsel cerdas karakteristik, yang memperkaya persepsi konsumen (Can dan Erdil, 2018). Kualitas sistem ini oleh sebagian besar peneliti diyakini mempengaruhi perilaku melalui nilai yang dirasakan (perceived value) (Pihlstrom dan Brush, 2008).

H3 = System Quality (kualitas sistem) memberi dampak terhadap brand loyalty (loyalitas merek)

\section{Desain Visual (Visual Design)}

Desain Visual adalah kualitas estetika suatu produk dan memiliki kepentingan besar bagi preferensi konsumen (Can dan Erdil, 2018) dan desain visual memberikan dampak yang signifikan terhadap kepuasan konsumen (Kim et al, 2016).

H4 = Visual design (desain visual) memberi dampak terhadap brand loyalty (loyalitas merek)

\section{Kesadaran Teknologi (Technology Consciousness)}

Masih belum banyak literatur mengenai konsep kesadaran teknologi (technology consciousness) namun terdapat literatur yang mengungkapkan bahwa konsep ini berasal dari kesadaran mode dan ekuivalen dengan keterlibatan technologi (Can dan Erdil, 2018). Lebih lanjut diungkapkan bahwa konsumen yang memiliki kesadaran teknologi yang tinggi akan terdorong untuk selalu mengadopsi teknologi 
terbaru dan akan lebih memperhatikan citra yang digambarkan oleh merek yang menambah inovasi pada produk merek (Can dan Erdil, 2018).

H5 = (Technology Consciousness) (kesadaran teknologi )memberi dampak terhadap brand loyalty (loyalitas merek)

\section{Positif Word of Mouth}

Word of mouth adalah indikator dari loyalitas merek yang memiliki dua dimensi yang bereda yaitu sikap dan perilaku. Word of mouth sendiri telah banyak digunakan dalam promosi mengingat keefektifan dan keefisienannya dan telah banyak digunakan dalam berbagai penelitian.

Salah satu penelitian terdahulu mengungkapkan bahwa word of mouth sebagai salah satu cara yang memiliki efek paling besar pada orang dan membujuk orang untuk membeli produk atau jasa lebih dari iklan lainnya karena biasanya orang mempercayai apa yang mereka dengar langsung dari orang lain (Maisam dan Mahsa 2016). Terdapat 2 kategori word of mouth yaitu positif word of mouth dan negatif word of mouth dimana positif word of mouth memberi dampak yang lebih daripada negatif word of mouth (East et al, 2017). Lebih lanjut dikatakan bahwa orang akan berespon lebih terhadap positif word of mouth dan lebih terbuka untuk dipengaruhi oleh positif word of mouth (East et al, 2017). Positif word of mouth juga mampu mengurangi dampak selama tahap evaluasi siklus pembelian konsumen atau dengan kata lain positif word of mouth dapat menjadi peredam risiko utama terkait dengan risiko kinerja maupun keuangan terhadap suatu produk (Sweeney et al, 2008). Penelitian Wong et al (2015) mengungkapkan bahwa kesetiaan merek merupakan salah satu penentu dari positif word of mouth.

H6 = Brand loyalty (loyalitas merek) memberi dampak terhadap positive word of mouth

\section{Niat Pembelian Ulang (Repurchase Intention)}

Niat pembelian ulang didefinisikan sebagai keinginan pelanggan untuk membeli secara terus-menerus dari perusahaan atau perusahaan (Ahmad et al, 2016). Niat pembelian ulang juga erat kaitannya dengan loyalitas merek mengingat niat pembelian ulang merupakan salah satu indikator dari loyalitas merek (Giovanis dan Athanasopoulou, 2018). Niat pembelian kembali mengacu pada probabilitas subjektif konsumen untuk melakukan patronisasi ulang pada toko online, dan merupakan penentu utama tindakan pembelian (Wu et al, 2014).

$H 7=$ Brand loyalty (loyalitas merek) memberi dampak repurchase intention 
Jika seluruh variabel dihubungkan maka akan diperoleh kerangka penelitian sebagai berikut :

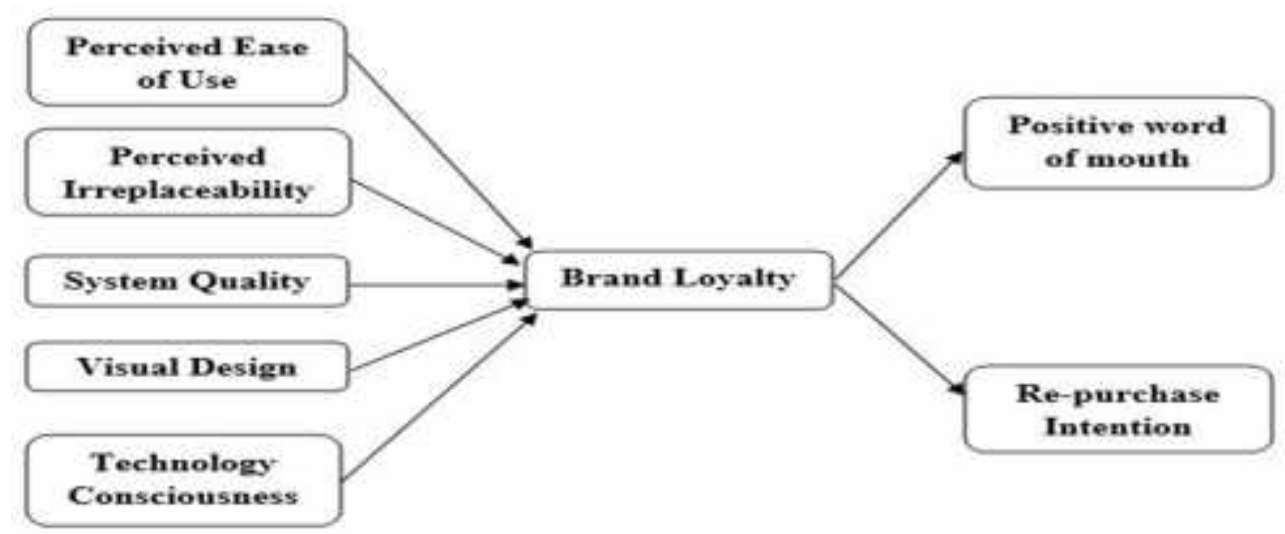

Gambar 1. Kerangka Konseptual

Sumber : Can dan Erdil (2018) dengan penambahan variabel

\section{METODE PENELITIAN}

Penelitian ini menggunakan sampel pada satu titik waktu tertentu atau dengan kata lain penelitian ini merupakan penelitian cross sectional (Leavy, 2017). Pengumpulan data pada penelitian ini menggunakan data primer dan memperoleh 110 sampel. Data yang diperoleh tersebut kemudian diseleksi untuk menyaring dan menyingkirkan data sehingga data dalam penelitian yang dapat digunakan menjadi 100 sampel. Dari 100 sampel diperoleh profil responden yang berupa demografi usia, jenis kelamin, dan lama waktu memiliki smartphone merek Oppo. Rentang usia yang digunakan pada penelitian ini adalah 16-20 tahun, 21 - 25 tahun, 26 - 30 tahun, $31-$ 34 tahun dan diatas 35 tahun. Dari berbagai kategori tersebut $39 \%$ responden berada pada rentang usia 16-20 tahun dan 37\% responden berada pada rentang usia $21-25$ tahun. Kategori kedua yang digunakan dalam meenggambarkan profil responden adalah jenis kelamin dimana pada penelitian ini mayoritas berjenis kelamin wanita sebesar $71 \%$. Kategori ketiga yang digunakan adalah lama memiliki smartphone merek oppo dimana pada kategori ini 35\% responden memiliki selama rentang waktu $1-2$ tahun dan $30 \%$ responden memiliki selama rentang waktu 3-4 tahun. Jika menarik kesimpulan berdasarkan tingkat presentase tertinggi maka profil responden penelitian ini didominasi oleh wanita pada rentang usia 16-20 tahun dengan lama memiliki smartphone merek Oppo selama 1-2 tahun.

Setalah profil responden diperoleh maka langkah selanjutnya adalah melakukan uji validitas dan reliabilitas. Pada uji validitas, penelitian ini menggunakan validitas convergent dan validitas diskriminan. Uji validitas convergent menggunakan nilai loading factor dimana nilai tersebut yang harus lebih dari 0,7. Hasil uji validitas 
convergent baik pada merek oppo menunjukan loading factor tiap indikator konstruk berada pada nilai diatas 0,7 yang menunjukan bahwa manifest variabel dari suatu konstruk berkorelasi tinggi (Ghozali dan Latan, 2015). Namun terdapat 2 indikator pembentuk niat pembelian ulang dieliminasi karena memiliki loading factor dibawah 0,7 . Selain uji validitas convergent, penelitian ini juga melakukan uji validitas diskriminan dimana hasil outputnya dapat dilihat di bawah ini.

Tabel 1. Hasil Uji Validitas Diskriminan

\begin{tabular}{|c|c|c|c|c|c|c|c|c|}
\hline & $\begin{array}{c}\text { Brand } \\
\text { Loyalt } \\
y \\
\end{array}$ & PEU & PI & $\begin{array}{c}\text { Positiv } \\
\text { e } \\
\text { WOM }\end{array}$ & $\begin{array}{l}\text { Repurchas } \\
\text { e Intention }\end{array}$ & SQ & TC & VD \\
\hline Brand Loyalty & 0,923 & & & & & & & \\
\hline Perceived ease of use (PEU) & 0,499 & $\begin{array}{c}0,87 \\
8 \\
\end{array}$ & & & & & & \\
\hline $\begin{array}{c}\text { Perceived irreplaceability } \\
\text { (PI) }\end{array}$ & 0,734 & $\begin{array}{c}0,61 \\
2\end{array}$ & $\begin{array}{c}0,84 \\
5 \\
\end{array}$ & & & & & \\
\hline Positive WOM & 0,874 & $\begin{array}{c}0,52 \\
6\end{array}$ & $\begin{array}{c}0,71 \\
6\end{array}$ & 0,951 & & & & \\
\hline Repurchase intention & 0,845 & $\begin{array}{c}0,41 \\
4\end{array}$ & $\begin{array}{c}0,70 \\
6 \\
\end{array}$ & 0,793 & 0,966 & & & \\
\hline System quality (SQ) & 0,849 & $\begin{array}{c}0,67 \\
6 \\
\end{array}$ & $\begin{array}{c}0,80 \\
3\end{array}$ & 0,787 & 0,773 & $\begin{array}{c}0,91 \\
7\end{array}$ & & \\
\hline $\begin{array}{c}\text { Technology conciousness } \\
\text { (TC) }\end{array}$ & 0,734 & $\begin{array}{c}0,39 \\
8\end{array}$ & $\begin{array}{c}0,60 \\
0\end{array}$ & 0,670 & 0,729 & $\begin{array}{c}0,73 \\
7\end{array}$ & $\begin{array}{c}0,82 \\
6\end{array}$ & \\
\hline Visual design (VD) & 0,754 & $\begin{array}{c}0,65 \\
1\end{array}$ & $\begin{array}{c}0,70 \\
9\end{array}$ & 0,741 & 0,629 & $\begin{array}{c}0,80 \\
3\end{array}$ & $\begin{array}{c}0,67 \\
1\end{array}$ & $\begin{array}{c}0,89 \\
3\end{array}$ \\
\hline
\end{tabular}
Sumber: Data Diolah (2020)

Pada uji reliabilitas menggunakan 2 cara yaitu dengan melihat nilai cronbach's Alpha dimana item yang diukur dapat diterima bila nilai chonbach's alpha pada rentang 0,6 sampai 0,7 dan lebih dari 0,8 dikatakan baik (Sekaran dan Bougie, 2016) dan composite reliability dimana nilai hasil uji diharapkan diatas 0.7 (Ghozali dan Latan, 2015). Hasil uji reliabilitas dapat dilihat pada tabel dibawah ini.

Tabel 2. Hasil Uji Reliabilitas

\begin{tabular}{ccc}
\hline & Chonbach's alpha & Composite reliability \\
\hline Perceived ease of use (PEU) & 0,902 & 0,931 \\
Perceived irreplaceability (PI) & 0,868 & 0,909 \\
System quality (SQ) & 0,905 & 0,941 \\
Technology conciousness (TC) & 0,843 & 0,895 \\
Visual design (VD) & 0,873 & 0,922 \\
Brand Loyalty & 0,942 & 0,958 \\
positive word of mouth & 0,948 & 0,966 \\
Repurchase intention & 0,928 & 0,965 \\
\hline
\end{tabular}

Sumber: Data Diolah (2020) 


\section{HASIL PENELITIAN}

Setelah setiap alat ukur dinyatakan reliabel mengingat seluruh nilai composite reliability dan chonbach's alpha setiap variabel lebih besar 0,7 sehingga dapat dilakukan pengujian hipotesa dimana ringkasan uji hipotesa dapat dilihat pada tabel dibawah ini.

Tabel 3. Hasil Uji Hipotesis

\begin{tabular}{lccc}
\hline \multicolumn{1}{c}{ Hipotesis } & $\begin{array}{c}\text { Koefisien } \\
\text { Jalur }\end{array}$ & $\begin{array}{c}\text { t } \\
\text { hitung }\end{array}$ & Hasil \\
\hline $\begin{array}{l}\mathrm{H} 1 \text { = Perceived ease of use memberi dampak terhadap brand } \\
\text { loyalty }\end{array}$ & 0,079 & 1,759 & $\begin{array}{c}\text { Tidak } \\
\text { terdukung }\end{array}$ \\
\hline $\begin{array}{l}\mathrm{H} 2 \text { = Perceived irreplaceability memberi dampak terhadap } \\
\text { brand loyalty }\end{array}$ & 0,086 & 1,720 & $\begin{array}{c}\text { Tidak } \\
\text { terdukung }\end{array}$ \\
\hline $\mathrm{H} 3=$ System Quality memberi dampak terhadap brand loyalty & 0,000 & 3,869 & Terdukung \\
\hline $\begin{array}{l}\text { H4 = Visual design memberi dampak terhadap brand loyalty } \\
\text { H5 = Technology Consciousness memberi dampak terhadap } \\
\text { brand loyalty }\end{array}$ & 0,118 & 1,565 & $\begin{array}{c}\text { Tidak } \\
\text { terdukung }\end{array}$ \\
\hline $\begin{array}{l}\text { H6 = Brand loyalty memberi dampak terhadap positive word } \\
\text { of mouth }\end{array}$ & 0,000 & 29,237 & Terdukung \\
\hline \begin{tabular}{l} 
H7 = Brand loyalty memberi dampak repurchase intention \\
\hline
\end{tabular} & 0,000 & 24,516 & Terdukung \\
\hline
\end{tabular}

Sumber: Data Diolah (2020)

$\mathrm{H} 1$ = Perceived ease of use (nilai kemudahaan penggunaan) memberi dampak terhadap brand loyalty (loyalitas merek). Pada pengujian hipotesa ini nilai $p$ diatas 0,05 yaitu sebesar 0.073 sehingga hipotesa ini ditolak. Dengan kata lain perceived ease of use (nilai kemudahaan penggunaan) tidak berpengaruh pada brand loyalty (loyalitas merek).

$\mathrm{H} 2$ = Perceived irreplaceability (nilai yang tidak tergantikan) memberi dampak terhadap brand loyalty (loyalitas merek). Pada pengujian hipotesa ini nilai p diatas 0,05 yaitu sebesar 0.086 sehingga hipotesa ini ditolak. Dengan kata lain Perceived irreplaceability (nilai yang tidak tergantikan) tidak berpengaruh pada brand loyalty (loyalitas merek).

H3 = System Quality (kualitas sistem) memberi dampak terhadap brand loyalty (loyalitas merek). Pada pengujian hipotesa ini nilai $p$ dibawah 0,05 dan nilai t hitung sebesar 3,869 diatas t tabel sebesar 1,986 sehingga hipotesa ini diterima. Melalui 
pengujian hipotesis ini nampak bahwa pada system quality (kualitas sistem) merek Oppo memiliki hubungan yang positif dan signifikan terhadap brand loyalty.

$\mathrm{H} 4$ = Visual design (desain visual) memberi dampak terhadap brand loyalty (loyalitas merek). Pada pengujian hipotesa keempat ini nilai $p$ diatas 0,05 yaitu sebesar 0.118 sehingga hipotesa ini ditolak. Dengan kata lain visual design (desain visual) smartphone merek Oppo tidak berpengaruh pada brand loyalty (loyalitas merek).

$\mathrm{H} 5$ = (Technology Consciousness) (kesadaran teknologi )memberi dampak terhadap brand loyalty (loyalitas merek). Pada pengujian hipotesis ini menunjukan bahwa technology consciousness (kesadaran teknologi) memiliki dampak signifikan dan positif terhadap brand loyalty (loyalitas merek). Hal tersebut nampak pada nilai $\mathrm{p}$ dibawah 0,05 dan t hitung sebesar 3,449 berada diatas t tabel.

H6 = Brand loyalty (loyalitas merek) memberi dampak terhadap positive word of mouth. Hasil uji hipotesis ini menunjukan nilai $p$ dibawah 0,05 sehingga dapat diakatakan bahwa brand loyalty (loyalitas merek) berpengaruh positif dan signifikan terhadap positive word of mouth

$\mathrm{H7}=$ Brand loyalty (loyalitas merek) memberi dampak repurchase intention. Hasil uji hipotesis ini menunjukan nilai $p$ dibawah 0,05 sehingga dapat diakatakan bahwa brand loyalty (loyalitas merek) berpengaruh positif dan signifikan terhadap repurchase intention (niat pembelian ulang).

Hasil pengolahan data juga menunjukan bahwa terdapat efek mediasi dimana brand loyalty (loyalitas merek) dapat menjadi mediasi bagi system quality (kualitas sistem) dan technology consciousness (kesadaran teknologi) terhadap positif WOM dan repurchase intention (niat pembelian ulang). Hal ini nampak pada nilai $p$ yang dibawah 0,05.

Tabel 3. Hasil Mediasi

Efek tidak langsung spesifik

\begin{tabular}{cc}
\hline Path Koefisien & P Values \\
\hline System Quality -> Brand loyalty -> Positif WOM & 0,000 \\
\hline Technology conciousness -> Brand loyalty -> Positif WOM & 0,001 \\
\hline System Quality -> Brand loyalty -> Re-purchase Intention & 0,000 \\
\hline Technology conciousness -> Brand loyalty -> Re-purchase Intention & 0,001 \\
\hline
\end{tabular}

Sumber: Data Diolah (2020) 


\section{PEMBAHASAN}

Dalam hasil uji hipotesis dapat dilihat bahwa terdapat hasil yang mendukung penelitian terdahulu dan yang berbeda dengan penelitian terdahulu. Pada uji hipotesa pertama perceived ease of use (nilai kemudahaan penggunaan) memberi dampak terhadap brand loyalty (loyalitas merek) yang memberikan hasil tidak terdukung. Hal ini mengkonfirmasi hasil penelitian terdahulu Can dan Erdil, (2018) yang mengungkapkan bahwa perceived ease of use (nilai kemudahaan penggunaan) memang tidak memberi efek apapun terhadap brand loyalty. Selain itu smartphone sudah bukan lagi barang mewah melainkan barang kebutuhan, sehingga hampir setiap individu memiliki dan mengoperasikan smartphone. Akibatnya perceived ease of use (nilai kemudahaan penggunaan) dirasa sudah tidak lagi relevan untuk penelitian ini dan dengan hasil ini diharapkan pada penelitian terkait smartphone, variabel ini dapat diabaikan. Hasil uji kedua dimana perceived irreplaceability (nilai yang tidak tergantikan) memberi dampak terhadap brand loyalty (loyalitas merek) yang memberikan hasil tidak terdukung. Hal tersebut menjadi masuk akal mengingat produk smartphone yang ditawarkan di Indonesia memiliki fitur yang mirip dan yang kemudian didorong dengan gencarnya produk baru yang cepat bermunculan. Akibatnya smartphone tidak memiliki keunikan yang menyebabkan merek tersebut tidak tergantikan. Hal tersebut pun dialami oleh merek Oppo dimana setiap smartphone memiliki fitur yang mirip. Profil responden yang didominasi oleh generasi muda juga patut diduga memberikan hasil yang berbeda dengna penelitian terdahulu.

Hasil menarik dari uji hipotesis adalah technology consciousness (kesadaran teknologi) memberi dampak terhadap brand loyalty (loyalitas merek) dimana hasil uji ini terdukung dan hasil ini tentu saja menarik mengingat hasil ini berbeda dengan penelitian terdahulu. Dengan terdukungnya uji ini maka peneliti menyakini technology consciousness (kesadaran teknologi) dapat digunakan lebih lanjut untuk memicu pembelian ulang. Terdukungnya technology consciousness (kesadaran teknologi) ini dapat merujuk pada penelitian Yeh et al (2016) yang mengungkapkan bahwa memang generasi muda (13-24 tahun) menggunakan smartphone untuk mengambil foto, melihat video dan mengeksplorasi teknologi baru. Jika merujuk pada penelitian Yeh et al (2016) dan menelaah profil responden dimana 76\% responden berusia 16-25 tahun, maka tidaklah mengherankan jika technology consciousness (kesadaran teknologi) berdampak terhadap brand loyalty (loyalitas merek).

\section{KESIMPULAN DAN SARAN}

Melalui penelitian ini menunjukan bahwa pada terdapat perceived ease of use, perceived irreplaceability dan visual design dirasa sudah kurang sesuai untuk membangun kesetiaan merek terkhususnya pada merek Oppo. Jika ditelaah lebih dalam lagi menggunakan profil responden penelitian ini maka ketiga variabel tersebut 
sudah kurang sesuai bagi generasi muda. Penelitian ini juga mengungkapkan bahwa kualitas sistem dan kesadaran teknologi yang lebih tepat digunakan untuk membangun loyalitas merek. Pada kualitas sistem tentu saja dirasa sesuai bagi anak muda yang lebih banyak menggunakan smartphone untuk mengambil foto yang membutuhkan kamera yang beresolusi tinggi, kinerja smartphone yang baik untuk mengelola hasil foto dan tentu saja tampilan layar yang jernih untuk melihat film maupun video. Oleh karena itu tidak mengherankan jika kualitas sistem pada smartphone, khususnya pada merek oppo berpengaruh secara positif bagi kesetiaan merek dan juga memberi pengaruh lebih besar daripada kesadaran teknologi yang nampak pada hasil t hitung yang paling besar.

Variabel kedua yang memberi pengaruh positif terhadap kesetiaan merek adalah kesadaran teknologi. Hal ini sejalan dengan keinginan untuk memiliki smartphone dengan sistem kualitas yang baik. Dengan kesadaran teknologi yang berarti pula maka akan mendorong untuk selalu mengadopsi teknologi terbaru sehingga akan mencari kualitas sistem yang terbaik. Penelitian ini juga menunjukan bahwa kesetiaan merek berpengaruh terhadap niat pembelian ulang dan positif word of wouth. Dengan demikian dapat ditarik kesimpulan bahwa merek Oppo dapat meningkatkan niat pembelian ulang dan positif word of wouth melalui 2 hal yaitu menawarkan produk-produk yang memiliki kualitas sistem yang berkinerja tinggi dan mempertahankan kesadaran teknologi dari target produk mereka dimana kedua hal tersebut akan mampu dijembatani dengan baik oleh kesetiaan merek. Merujuk pada hasil penelitian maka bagi penelitian yang akan datang, peneliti meyakini bahwa ada keterkaitan erat antara kesadaran teknologi dan sistem kualitas sehingga hal tersebut dapat menjadi landasan bagi penelitian yang akan datang. Selain itu dengan melalui penelitian ini diketahui bahwa desain visual tidak mampu memberikan pengaruh pada kesetiaan merek, hal ini tentu menarik untuk melihat dampak desain visual pada berbagai merek smartphone terhadap kesetiaan merek

\section{DAFTAR PUSTAKA}

Ahmad, Z., Jun, M., Khan, I., Abdullah, M., \& Ghauri, T. A. (2016). Examining Mediating Role of Customer Loyalty for Influence of Brand Related Attributes on Customer Repurchase Intention. Journal of Northeast Agricultural University (English Edition), 23(2), 89-96.

Alto, Paul. 2019. Indonesian smartphone market Q4 2018. https://www.canalys.com/newsroom/samsung-leads-in-indonesiansmartphones-as-market-surges-ahead-to-close-2018-up-171

Amin, M., Rezaei, S., \& Abolghasemi, M. (2014). User satisfaction with mobile websites: the impact of perceived usefulness (PU), perceived ease of use (PEOU) and trust. Nankai Business Review International, 5(3), 258-274. 
Can, Y., \& Erdil, O. (2018). Determining Antecedent of Re-Purchase Intention: The Role of Perceived Value and Consumer's Interest Factor. International Business Research, 11(4), 17-31.

Chen, Y. S., Chen, T. J., \& Lin, C. C. (2016). The Analyses of Purchasing Decisions and Brand Loyalty for Smartphone Consumers. Open Journal of Social Sciences, 4, 108-116.

East, R., Romaniuk, J., Chawdhary, R., \& Uncles, M. (2017). The impact of word of mouth on intention to purchase currently used and other brands. International Journal of Market Research, 59(3), 321-334.

Giovanis, A., \& Athanasopoulou, P. (2018). Understanding lovemark brands: Dimensions and effect on Brand loyalty in high-technology products. Spanish Journal of Marketing-ESIC, 22(3), 272-294.

Ghozali, I., \& Latan, H. (2015). Partial Least Squares, Konsep, Teknik dan aplikasi menggunakan program SmartPLS 3.0. Badan Penerbit - Undip.

Hair, J. F., Black, W. C., Babin, B. J., \& Anderson, R. E. (2014). Multivariate data analysis: Pearson new international edition. Pearson Higher Ed.

Khan, S. A., Ramzan, N., Shoaib, M., \& Mohyuddin, A. (2015). Impact of word of mouth on consumer purchase intention. Age, 18(21), 78.

Kim, M. K., Wong, S. F., Chang, Y., \& Park, J. H. (2016). Determinants of customer loyalty in the Korean smartphone market: Moderating effects of usage characteristics. Telematics and Informatics, 33(4), 936-949.

Leavy, P. (2017). Research Design : Quantitative, Qualitative, Mixed Methods, ArtsBased, and Community-Based Participatory Research Approaches. The Guilford Press : New York

Liao, S. H., Chung, Y. C., Hung, Y. R., \& Widowati, R. (2010, December). The impacts of brand trust, customer satisfaction, and brand loyalty on word-of-mouth. In 2010 IEEE international conference on industrial engineering and engineering management (pp. 1319-1323). IEEE.

Maisam, S., \& Mahsa, R. D. (2016). Positive word of mouth marketing: Explaining the roles of value congruity and brand love. Journal of Competitiveness, 8(1), 19-37.

Park, Y., \& Chen, J. V. (2007). Acceptance and adoption of the innovative use of smartphone. Industrial Management \& Data Systems, 107(9), 1349-1365.

Pedeliento, G., Andreini, D., Bergamaschi, M., \& Salo, J. (2016). Brand and product attachment in an industrial context: The effects on brand loyalty. Industrial Marketing Management, 53, 194-206.

Pertiwi, K. Wahyunanda. 2018. Vendor Ponsel China Kuasai Lebih dari Separuh Pangsa Pasar Indonesia. https://tekno.kompas.com/read/2018/12/20/10040037/vendor-ponsel-chinakuasai-lebih-dari-separuh-pangsa-pasar-indonesia

Pihlström, M. (2008). Perceived value of mobile service use and its consequences. Svenska handelshögskolan.

Pihlström, M., \& Brush, G. J. (2008). Comparing the perceived value of information and entertainment mobile services. Psychology \& Marketing, 25(8), 732-755.

Schifferstein, H. N., \& Zwartkruis-Pelgrim, E. P. (2008). Consumer-product attachment: Measurement and design implications. International journal of design, 2(3). 
Sekaran, U., \& Bougie, R. (2016). Research methods for business: A skill building approach. John Wiley \& Sons

Sweeney, J. C., Soutar, G. N., \& Mazzarol, T. (2008). Factors influencing word of mouth effectiveness: receiver perspectives. European journal of marketing, 42(3/4), 344-364.

Wu, L. Y., Chen, K. Y., Chen, P. Y., \& Cheng, S. L. (2014). Perceived value, transaction cost, and repurchase-intention in online shopping: $A$ relational exchange perspective. Journal of Business Research, 67(1), 2768-2776.

Wong, M. C. M., Kwok, M. L. J., \& Lau, M. M. (2015). Spreading Good Words: The Mediating Effect of Brand Loyalty between Role Model Influence and Word of Mouth. Contemporary Management Research, 11(4), 313-326.

Yeh, C. H., Wang, Y. S., \& Yieh, K. (2016). Predicting smartphone brand loyalty: Consumer value and consumer-brand identification perspectives. International Journal of Information Management, 36, 245-257. 